KONSTANTIN LiDin

Irkutsk State Railway University, Russia

\title{
Personification of genius loci - innovations on the base of geographical identity
}

Today's communes and regions of Europe are involved in a continuous and fatal battle for employment increase and well-being growth. It is expected of the local authorities by the inhabitants and the enterprises. To expand possibilities, cities and regions need to possess the abilities to attract investors, enterprises, inhabitants and tourists.

For locations, as well as goods and services, skilful marketing is necessary. Each city, settlement or community should define the special lines and effectively extend the information on the competitive advantages among "potential and existing clients", whose support they achieve. It is a serious problem. To develop competitive advantage, locations need to reflect on the past, the present and the future. They should depict in detail their weak and strong points, and also the possibilities arising before them, and the threats. It is necessary to define what resources locations-competitors have, and to find methods of differentiation and positioning, so as to have a place in the consciousness of the target groups.

Europe consists of more than 100 thousand competing territorial units which need to attract potential consumers by means of creating a bright and actual image. Without having the unique, characteristic image, a potentially attractive place can remain unnoticed on the enormous European market of places. Unfortunately, there is not enough methodology of the location-image creation.

The central questions addressed are:

- What should be the methodology of creating a unique image of a place?

- What qualities should the image of a place possess for the competitiveness of this place to rise successfully?

- What sources can generate a successful image of a place in a modern crisis situation in Europe?

An interdisciplinary approach combines qualitative research and comparative methodologies with modelling to explore the dynamic effects of development models as they are implemented in specific contexts, at micro and macro-levels.

We hypothesize that:

- The unique image of a place in the implicit form exists as the complex of historical and geographical features of the place, 
- The existing image of a place can be revealed and expressed in concrete forms,

- Only such image of a place which leans against the real historical and geographical base is able to raise competitiveness of a place.

The objective of this research is to improve our understanding of a place image and its influence on the competitiveness of a place. In the last decades, the emotional essence of a place image has made considerable impact on the economic and demographic development of places. This project will allow us to study quantitatively the increasing value of a place image as determinative of its appeal. Our project, thus, aspires to improve measurements of features of a place image for the purpose of management of local-level attractiveness.

The key aspect of a place image is its emotional essence. What emotions fill a place image and to what extent these emotions are claimed by investors defines the competitiveness of the place.

The phenomenon of emotional communication of a person with the surface of the Earth is one of the central objects of study in humanitarian geography. The terms "topophilia/ topophobia", proposed by Tuan Yi-Fu in 1976, were widely adopted both by English-speaking, and other scientific schools of cultural geography around the world. Now the given terms are understood basically as a complex affective, emotional (empathic) reaction of a person to the perception of geographical objects - in a greater degree than the cognitive, rational component of interaction between a person and the surface of the Earth.

Further development of the given direction in humanitarian geography, however, is disturbed by an insufficient state of readiness of the conceptual and theoretical devices treating emotions. The affective sphere remains too mystified, poeticized, and is not enough reflected within the limits of positive knowledge. Methodological deficiencies in the field are expressed, first of all, in insufficient understanding of the basic definitions.

Among methodological deficiencies of the theory of emotions, it is necessary to allocate the following:

1. Illegibility of the basic definitions. In the words of Carroll Izard, psychology of emotions is a science which basically doesn't address the essence of things which it studies,

2. Absence of a uniform methodological basis for studying the whole range of displays of emotional sphere - from medical to culturological ones,

3. Absence of accurate criteria of distinguishing the positive (healthy, adequate) emotional conditions from negative (pathological, inadequate) ones,

4. Absence of the valid techniques for measurement of emotions.

In our work, we offer a definition of emotions as characteristics of a stream of the information proceeding through contact border of the human person (the border separating the person from the world around). In this case, perception of a geographical object by a person is regarded as a bilateral process depending both on the properties of the object, and the condition of the perceiving subject.

Consideration of emotions as characteristics of an information stream has formed a basis for the model working out "spaces of emotions" - the two-dimensional aligned space, which has as the coordinate axes two orthogonal characteristics of a stream - intensity and orderliness. So, the most intensive stream of the information on the world around the person is received in the condition "interest - excitation", and the least intensive - in the condition "grief". Orderliness (connectivity) of an information stream is maximal in the condition "conscience", and is minimal in the condition "fear". 
Axes of space of emotions can be gradated in the conditional points expressing intensity of experience of this or that emotion. For example, the emotion "fear" in process of increase can be called as follows: mistrust, suspiciousness ( 1 conditional point), uneasiness ( 2 points), fright, fear (3 points), horror (4), panic (5 points). Panic is called the fear of extreme intensity. The further increase of chaos level is incompatible with the physiological processes in an organism of the perceiving subject, that is, is fatal. Similarly, any emotion has the physiological limit of intensity. Thus the model becomes quantitative in character.

The information model "spaces of emotions" allows the methodological problems which are a barrier for using the concept of topophilia/topophobia.

Research has shown that conditions of comfort, satisfaction and happiness cannot be attached to any area of space of emotions. Generally, "the happiness area" is an individual phenomenon. However, each culture - state, national, regional, corporate and so on - includes, as an obligatory element, the hierarchy of emotions according to their socially accepted value. In each community, there is an idea of the most valuable and desirable emotion, and such representations make the base values and the purpose of existence of the given community.

Influence of the geographical environment on individual and social mentality is expressed in a mutual process: features of regions build up the character of socially approved emotional conditions, and the representations of happiness, accepted in a society, build up the character of anthropogenic influence on the geographical environment.

Dragon is one of the most ancient images in human culture. It is a being combining in its corporal shape the signs of a person, an animal, a bird and a reptile. Character of a dragon is inconsistent and changeable: a dragon possesses magic abilities, it can be wise and farsighted, but it is subject to attacks of unreasonable greed, anger and passion, and even an absolutely simple-minded person can sometimes outwit it or argue with it.

The image of a dragon figures prominently especially in the culture of China. In this "culture of a dragon" it is perceived positively, as the carrier of a variety of valuable qualities - nobleness, wisdom, and will. To see a dragon in dreams or visions is the sign of a propitious omen, foretelling the birth of a great governor. Many legendary kings of ancient China come directly from dragons. For example, "the ideal governor" Shun is described as a person of small growth, humpbacked, with skin of black colour and with two pupils in each eye. His conception from a bright rainbow (one of the symbols of a dragon) proved to be true due to the presence of "dragon labels" on his forehead. The inventor of grain cultivation and herbal treatment, the great hero and governor Shen-nun, also has been conceived from a dragon, and was born with a body of a snake, a bull's head, a tiger's nose and skin of green colour. The greatest hero of the Chinese mythology, emperor Yui, looked like a dragon, with two horns on his head.

The term Dragon-legislator, or Dragon-leader, specifies semantic coincidence in the most ancient, Neolithic origin of this image, in the treatment of the dragon cultures of Asia and America. Probably, the ancient inhabitants of Northern Asia transferred to the American continent the cult of dragons Ketzalkoatl and Kukulkan, great teachers and legislators. The image of a dragon spread to all Pacific regions: images of an animal with wings and a coiling animal body can be found among petroglyphs of Australia and in the motives of wooden carving of Oceania natives.

The law symbolised by the Dragon is not to be corrected, as the one invented by people. These are eternal and firm laws of nature. They are relentless, and one who breaks them experiences their cruel and dangerous effect. But one who is respectful of the laws of nature and understands them, can use them to achieve riches, health and happiness. 
Development of the image of a dragon in the west of the Euroasian continent and in Africa has led to its stratification.

Gods of underground waters, carriers of chaotic formlessness and lawlessness were embodied in an image of the Snake (Worm). The Egyptian snake-god Apep, the Babylon goddess Tiamat, or the Hittite Kumarbi, were symbols of senselessness and Chaos. From recent cultures, the image of the Snake in its primary form was kept by the culture of India. Indian Naga easily change shape or even are absolutely shapeless, they look like "colubrine beings resembling clouds". In the hierarchy of spiritual beings, they have a place between Devas and Yakshas, among the lowest creatures subject to illusions of the Maya - the deceptive, apparent world (in which the majority of people live, too). Only one Buddha can pacify their incorrect, sensitive and irascible character. Naga often got in human shape into the environment of the Teacher and even tried to get mixed in the number of his followers.

The Snake, contrary to the Dragon, is understood as an embodiment of lie and inconstancy. It harms a person, at all without wishing that, and is simply of the deceptive essence. So, the Snake in the African cultures of Dogon and Benin steals water in all manners - drinks the rivers, carries away lakes and devours clouds, dooming people to a drought. The Snake of the ancient Greeks - the Hydra (as well as Mesopotamic Tiamat) - symbolises underground waters. In these seismically active regions, the movement of underground waters can really have unpredictable and uncontrollable, deceptive character.

Unlike the Dragon, the Snake in legends, sagas and fairy tales are represented legless or with two paws. What is more, it is ugly and disgusting, its breath is fetid, and its blood is black and poisonous. In some embodiments the European Snake not only crawls, but also flies, like the Dragon. But its wings are not plumed, like those of a bird, nor leathery, like those of a bat. Slavic Zmei-Gorynych has the wings in general like paper. The western Slavs name flying dragons "obajasniki". Curiously, in the word the Old Slavic word is present, "obaviti, obajati", meaning "to bewitch" (originally - to stipulate, persuade, enchant). In ancient Russian texts (for example, in Azbukovniki) there is a close term "obajanici", meaning"sorcerers". In modern Russian there is a related word "obajat" in the sense "to charm/ charming", and it also has a shade of dangerous magic influence; after all, the Snake first of all is able to deceive and lie very convincingly, seductively.

For our research, we have accepted the definition of essence of a dragon not associated with its appearance - with the number of extremities or plumage of wings. We will define a dragon as such a mythical being that symbolises a certain set of personal qualities: a combination of conscience, debt, and honour with curiosity, interest in life and propensity to creativity. For us, the dragon means personification of healthy, valid relations between the Person and the Nature.

Recently, a number of cities have officially claimed the symbol of the Dragon. The analysis has shown that these Dragons bear various emotional essences. So, a sculpture of Smok Wawelski (1972, author Bronislaw Chromy) contains emotions of the group "fear" in middle intensity (uneasiness). The sculpture of a Dragon has served as a city symbol in Austrian Klagenfurt since 1583. Similarly, the copper dragons of Ljubljana (the beginning of the $20^{\text {th }}$ century), a dragon of the capital of Tatarstan, the Kazan city, and the dragons in Bulgarian Varna (2010): all these sculptures bear various variants of emotions from the adjoining groups "interest" and "anger". In Vietnam, dragons symbolize the royalty. One thousand years ago, king Ly Thai To, in the fifth generation a descendant of Shen-Nun, established the city of Thang Long (Flying Dragon, Hanoi). In the Vietnamese tradition, images of a dragon bear emotions of the group "pleasure - pride". 
Using materials of local folklore, we have constructed a series of Dragon images for the southeast area of Bulgaria. The area is characterized by high concentration of historical and archaeological sites, and in great degree lives on cultural tourism. Such cities as Shumen, Veliky Preslav, Sozopol, Pomorie, Pliska and so on, were investigated for the purpose of specific historical and geographical features detection. Features of each place were reflected in the individual character of the corresponding Dragon. Within a year, an exhibition "Bulgaria. Habitats of dragons" was successfully presented in several cities of the region. Negotiations are conducted with the city halls of the cities about the use of images of dragons for innovative development of cultural tourism.

Summing up, innovative development of a place should necessarily include its individual positioning. Research into, and expression of geographical identity of a place is conveniently carried out, using an image of a Dragon as the personification of "genius loci". The methodology has been confirmed on the example of a number of cities in the southeast area of Bulgaria.

\section{REFERENCES}

Izard C., 1991, The Psychology of Emotions, Plenum Press, New York.

Kotler P., Asplund C., Rein I. \& Haider D., 1999, Marketing Places Europe: How to Attract Investments, Industries, Residents and Visitors to Cities, Communities, Regions and Nations in Europe, Financial Times Prentice Hall, London; 2nd edition.

Kotler P., Jatusripitak S., Maesincee S., 1997, The Marketing of Nations. A Strategic Approach to Building National Wealth, The Free Press, New York.

Lidin K., Sumenkova M. Competitiveness and the emotional essence of the region image. In: Proceedings of the 26th International Scientific Conference on "Impact of Crisis on the Activity of Enterprises and Changes in the Spatial Structures of Industry and Services" edited by Zbigniew Zioło and Monika Borowiec, Warsaw-Cracow 2010 - pp. 37-50.

Lidin K., Quantitative measurements in the market of emotions. In: Proceedings of the IV World Congress on Communication and Arts - WCCA'2011. "Interactive Expansion of Knowledge: Communicating with Art in the Information Era", São Paulo in Brazil, 17-20 April 2011. Mackenzie Presbyterian University Publishers, vol. 2, pp. 137-144.

Tuan Yi-Fu, 1974, Topophilia (a study of environmental perception, attitudes, and values), Prentice Hall, Englewood Cliffs, NJ.

Tuan Yi-Fu, 2004, Place, Art, and Self, University of Virginia Press, Santa Fe, NM, in association with Columbia College, Chicago, IL.

Лидин К.Л. Город-пациент. К исследованиям эмоциональной атмосферы городов // Проект Байкал/Project Baikal, № 29-30, 2011. Pp. 33-36.

Рагулина М.В., 2004, Культурная география: теории, методы, региональный синтез, Иркутск: Изд-во Института географии СО РАН.

Щукин В.Г. Заветное «где». Топофилия и методы ее исследования // Вопросы философии. 2008. № 4. Рp. 69-90.

Замятин Д.Н., Замятина Н.Ю., Митин И.И. Моделирование образов историко-культурной территории: методологические и теоретические подходы - М.: Институт наследия, 2008. - p. 760. 

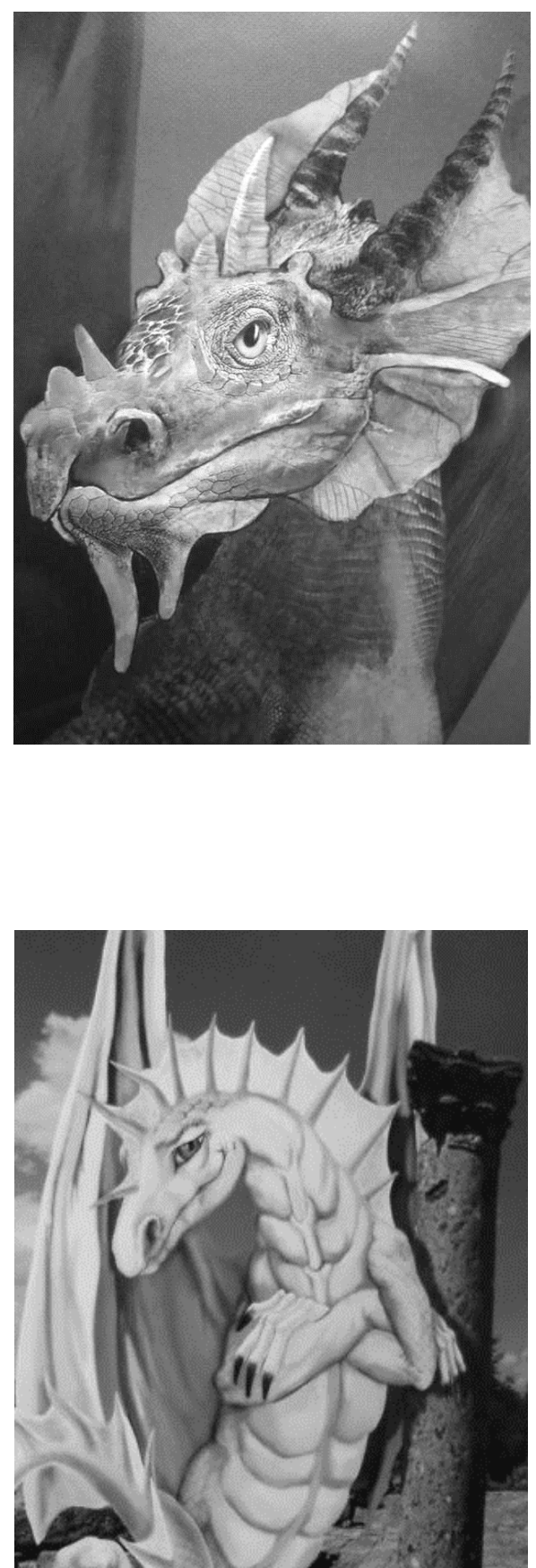

„Portrait” of one of seven dragons developed by us on folklore materials of Shumen area / Emotional essence ,irony” (a working name the Artful Dragon). The description and emotional filling of K. Lidin and N. Ushkova, art realization E. Suslova
„Portrait” of the Dragon of Velikiy Preslav. Emotional essence is between ,interest" and ,pleasure-proud" (a working name the Sexual Dragon). The description and emotional filling of K. Lidin and N. Ushkova, art realization E. Suslova 


\section{Personification of genius loci - innovations on the base of geographical identity}

Innovative development of a place is necessary associated with the individual positioning of the place. Europe consists of more than 100 thousand competing territorial units, which need to attract the potential consumers by means of creating a bright and actual image. Without having the unique, characteristic image, a potentially attractive place can remain unnoticed on the enormous European location market.

The objective of this research is improving our understanding of a place image and its influence on competitiveness of the location. Over the last decades, the emotional essence of place image has made considerable impact on economic and demographic development of places. This project will allow us to study quantitatively the increasing value of a place image as determinative of its appeal. Our project, thus, aspires to improve measurements of features of a place image for the purpose of management on the level of location attractiveness.

The research into and expression of geographical identity of a place is convenient to carry out, using the image of a Dragon as the personification of «genius loci». The methodology is confirmed on the example of a number of cities in the southeast area of Bulgaria.

PhD Konstantin L. Lidin

Irkutsk State Railway University, Russia

e-mail: lidinkl@hotmail.com 